\title{
Damage Potential and Losses Resulting from Snow Avalanches in Settlements of the Canton of Grisons, Switzerland
}

\author{
SVEN FUCHS ${ }^{\star}$ and MICHAEL BRÜNDL \\ WSL Swiss Federal Institute for Snow and Avalanche Research SLF, Flüelastrasse 11, 7260 \\ Davos Dorf, Switzerland
}

(Received: 13 February 2003; accepted: 19 February 2004)

\begin{abstract}
In the field of natural hazards, risk is usually expressed as a function of probability of occurrence and damage potential. A key factor in the development of avalanche risk is a change in damage potential. In this paper, the development of damage potential and losses is analysed for settlements in the canton of Grisons, Switzerland for the period between 1950 and 2000. The spatial development patterns of the residential population and the insured value of buildings on a municipal level are described. These patterns are overlain by an accentuated occurrence of avalanches that caused damage to buildings. Extensive results from areas threatened by avalanches in the municipality of Davos are presented. Although the natural avalanche activity remained constant during the last decades, the total amount of damage decreased due to mitigation measures. The example of the municipality of Davos shows that mitigation measures are able to compensate an increase of tangible assets which leads to a reduced avalanche risk compared to earlier decades.
\end{abstract}

Key words: risk analysis, damage potential, snow avalanches, settlements, building insurance, losses, tangibles, temporal variability

\section{Introduction}

A world-wide increase in the frequency and magnitude of natural hazards, and consequently in corresponding losses, is well documented (see e.g. Berz, 2000; Jakobi et al., 2001; Munich Re, 2003). In mountain areas, natural hazards, such as catastrophic snow avalanches, are an inescapable part of life. Even if their occurrence is rare, they represent a serious risk to human life and property, particularly because they belong to the so-called involuntary risks. Quantitatively, in the field of natural hazards, risk is generally defined as the product of the probability of occurrence of a dangering process $(p(a))$ and the expected damage, the latter being a product of the damage potential $(d)$ and the corresponding vulnerability (v) (e.g. Varnes, 1984, see Equation (1)):

$$
R=p(a) \cdot d \cdot v
$$

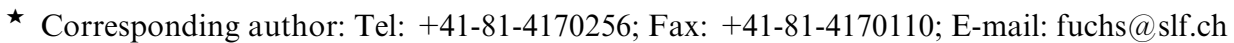


Unlike the economic definition of the term risk, this definition considers only the negative effects of a certain event and not the opportunities that might result from it, such as more orders for the local construction industry after an damaging event. A reciprocal relationship between the probability of occurrence and the damage potential is postulated: with the same risk, small amounts of damage can occur more frequently, while large amounts of damage are less likely to occur. This problem is sometimes treated by introducing a so-called risk aversion factor into Equation (1). This definition is not undisputed, however, especially in social sciences (Renn, 1992).

The damage potential to settlements can be divided into three main categories: affected persons, damaged or destroyed buildings and damaged or destroyed infrastructure. Focusing on buildings and thus ignoring damage to infrastructure, the damage potential can be expressed as

$$
d=\left(d_{\mathrm{P}}+d_{\mathrm{B}}\right)
$$

where $d_{\mathrm{P}}$ is affected persons, $d_{\mathrm{B}}$ is damaged or destroyed buildings.

Following this definition, the main objectives of risk analysis for natural hazards are (1) hazard identification, (2) estimation of probability of occurrence and (3) assessment of damage potential (Heinimann et al., 1998; Borter, 1999; Fuchs et al., 2002).

As investigations have shown, the long-term natural avalanche activity in the Alps seems to be constant (Schneebeli et al., 1998; Laternser, 2002), although it is pointed out that the variability of events makes an exact statement difficult. A change in avalanche activity is not expected in the near future, even if snow precipitation in high alpine areas is more accentuated during the winter (Watson and the Core Writing Team, 2001) or more in sum (Wanner et al., 2000). Due to the construction of mitigation measures, the number of devastating avalanches (Schneebeli et al., 1998) as well as the corresponding losses have declined over the last 50 years in Switzerland. In this paper we concentrate on the change in damage potential between 1950 and 2000.

The value of potential damage to buildings can be obtained from insurance policies or estimated from values established when assessing building structures. Due to different strategies in the economic assessment of human life (see e.g. Viscusi, 1993), details of affected persons should be expressed as a clear number of casualties and deaths or - if the potential damage is examined - the number of people living or staying in a defined area at a certain point in time.

Until now, there have been few investigations concerning losses due to alpine natural hazards (SLF, 2000; Jóhannesson and Arnalds, 2001; Nöthiger et al., 2002) and the temporal variability of damage potential in settlements (Wilhelm, 1997a; Jamieson and Stethem, 2002). The aim of this paper is to partially fill this gap. In a first step, the development of the damage potential as well as losses paid for avalanche damage by the obligatory building insurer 
of the canton of Grisons, Switzerland for the period between 1950 and 2000 is quantified.

The canton of Grisons is located in the south-east of Switzerland (see Figure 1) and covers $7,100 \mathrm{~km}^{2}$. Around $80 \%$ of the territory in the canton is located above $800 \mathrm{~m}$ a.s.l., with high relief, which explains the susceptibility to natural hazards, especially snow avalanches. In addition to an evaluation of the insurance data, an overview of fundamental changes in land use and population density on the municipal level is given. In a second step, detailed results from the municipality of Davos, Grisons, are presented. The residential area of Davos is located between 1,500 and 1,900 m a.s.l. Analysis of data based on the destructive avalanche database of the Swiss Federal Institute for Snow and Avalanche Research (SLF) has shown that the number of avalanches that caused damage to buildings is highest within the canton of Grisons. Patterns and values of buildings within avalanche-affected areas were examined for the time period between 1950 and 2000. In the third step, changes in concentration of values for the canton of Grisons are evaluated and compared with the general increase in value due to inflation.

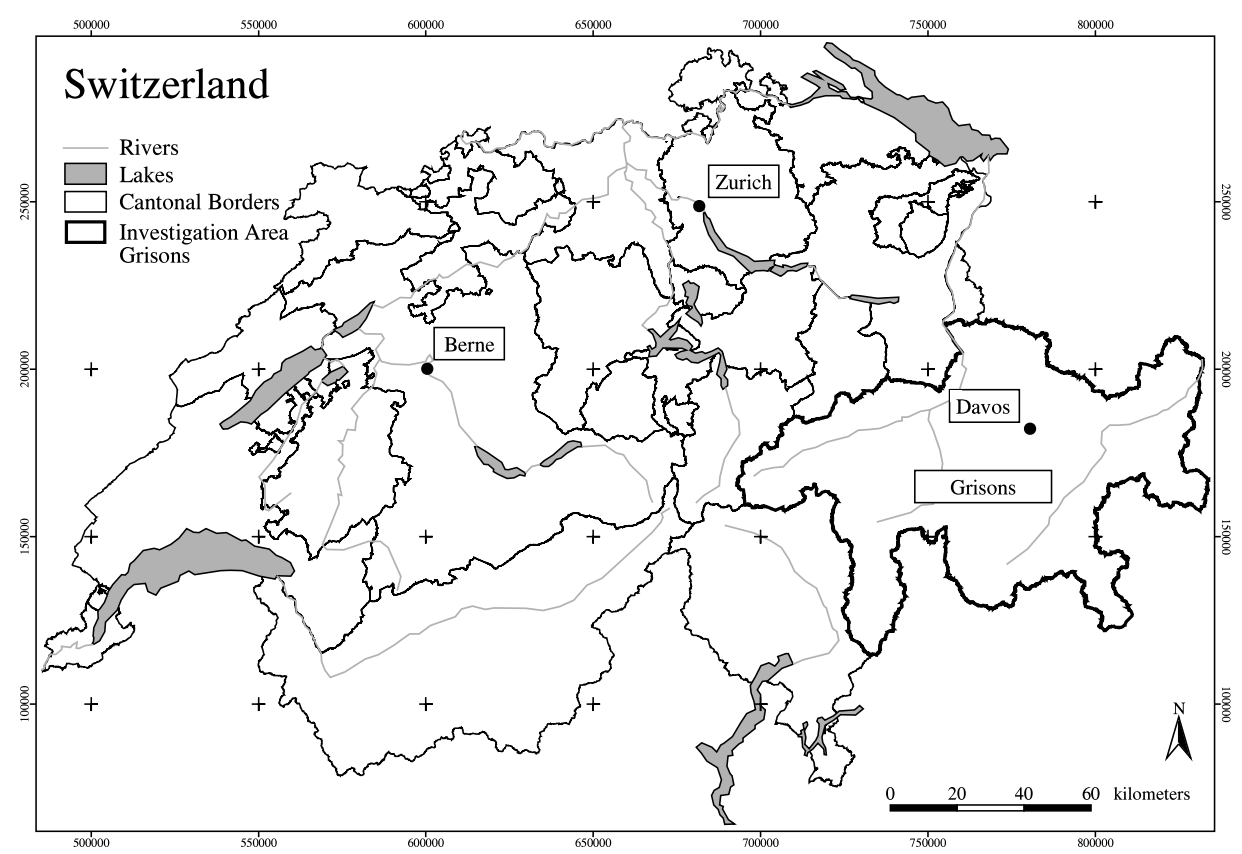

Figure 1. Location of the investigation area. The canton of Grisons, situated in the south east of Switzerland, is the largest canton of the country. Around $80 \%$ of its territory is located above $800 \mathrm{~m}$ a.s.l. with high relief, which explains the region's susceptibility to natural hazards. 


\section{Methods}

To obtain a general picture of the development of key variables within the canton of Grisons, the relevant data were collected on a mesoscale resolution of districts. Data concerning the size of the resident population in the canton of Grisons were made available by the Swiss Federal Office for Statistics. The data were prepared statistically for the years 1950-2000 in annual steps. The number of insured buildings and the annual sums paid out for damage were made available by the mandatory building insurer. Changes in number and value were examined statistically for the same time period. All data were stored in a relational data base. This procedure permits on the one hand an effective statistical evaluation and on the other hand the integration into a geographical information system (GIS) with the appropriate possibilities for analysis.

The basis for detailed investigations in the municipality of Davos was provided by the zoning plan, which was made available by the local administration. This plan contains detailed information about the location and the area of every plot. Additional information, such as year of construction, type of building and original and current value were integrated from the data base of the land registry office. The zoning plan was processed and overlaid with the building plan, which contains the affiliated built up surface area, within a GIS. In a second step, the avalanche run-out areas were determined using the 1999 avalanche hazard map. This map contains three grades of possible pressure impact and reoccurrence intervals, shown in red, blue and yellow (see Appendix). The hazard zones were buffered by $10 \mathrm{~m}$ in the GIS to clarify the sensitivity of the damage potential when allowing for an error in the spatial extent of the hazard zones. In a next step, these process areas were overlaid with the building layer. As a result, all buildings within the hazard zones could be classified according to the type of zone. For every intensity class, a detailed analysis of the history of the buildings was carried out. The development of cumulative insured values was calculated and statistically analysed. The total amount of insured values and the averaged values per building and zone were established. By using this method, it is possible to reconstruct the development of damage potential within the process-relevant range for a specific time period.

\section{Results}

The size of the residential population as well as the number and value of buildings are relevant data for the investigation of damage potential. These developments are presented below. First, changes in the number of inhabitants, in the value of buildings and in losses are summarised for the canton of Grisons. Second, the development of the settlement is presented for the avalanche process areas within the municipality of Davos (a case study was 
carried out in the run-out zone "Albertitobel") and third, the concentration of tangible assets due to a higher density of buildings is compared with the general increase in the monetary value due to inflation.

\subsection{DEVELOPMENT OF THE RESIDENTIAL POPULATION IN THE CANTON OF GRISONS}

The residential population shows a variety of spatial disparities in the canton, leading to different developments in damage potential (see Figure 2). Between 1950 and 2000, the total residential population rose by $30 \%$. The average increase in population per municipality was approximately $20 \%$, but there was considerable spatial variation. Almost $50 \%$ of all municipalities experienced a decline in the number of residents, but only $16 \%$ of the whole population lived in these municipalities. These municipalities could be viewed as classic peripheral areas (Bätzing, 1993); around three quarters of them have experienced a decline in population since 1870 . In the year $2000,16 \%$ of all municipalities had less than 100 inhabitants. In only $7.5 \%$ of all municipalities did the residential population double within the last 50 years, with approximately $20 \%$ of all inhabitants living in these areas. The highest growth rates were found in tourist areas such as the Upper Engadin, Arosa or the Flims-Laax region and in industrial and business agglomerations like the Lower Rhine valley or the municipalities along the northern stretch of the San Bernardino motorway.

\subsection{DEVELOPMENT OF VALUES IN THE CANTON OF GRISONS}

Between 1950 and 2000, the absolute number of buildings doubled, while the average increase in the municipalities was about $80 \%$. In the canton of Grisons, smaller and bigger municipalities show different development trends. However, the spatial pattern differs from the pattern of the residential population described in the previous section (see Figure 3). The insured cumulative values of all buildings have risen by a factor of 6 , adjusted for inflation. Taking into account the increased number of buildings during this period, the average insurance value per building has risen by a factor of 3.4 (see Figure 4). This means that buildings are worth much more nowadays than 50 years ago. The total value of insured buildings amounts to $€ 45$ billion.

There was great spatial variation in the change of values. It is conspicuous that the largest increase in insured values correlated well with the belowaverage growth rates in the size of the residential population and in the number of buildings. The reason might be in the history of traditional health resorts like Pontresina (Bernina region) or Scoul (Lower Engadin): the economic development of these municipalities - and consequently an increase in values - started at the end of the 19th century, while our period under 

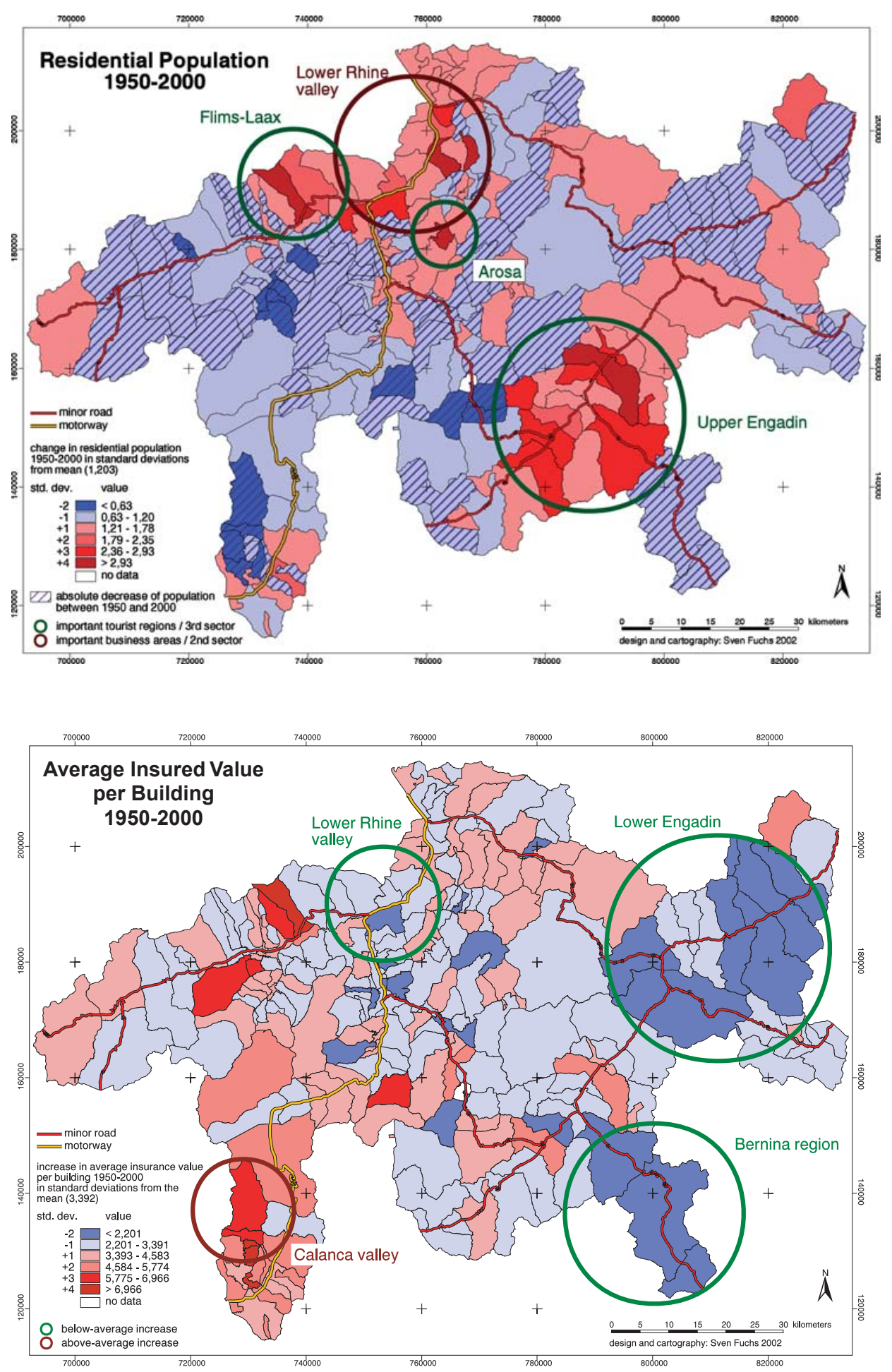
Figure 2. Development of the residential population in the canton of Grisons. The figure illustrates the relative change in residential population by standard deviations from the mean, which is an average factor of 1.2 for the whole canton within the period between 1950 and 2000. Regions with a high growth rate due to the development of the tertiary sector (mostly due to winter tourism) are marked with green circles. Regions with high growth rates due to an increase in the secondary sector (industrial and business agglomerations in the Rhine valley) are marked with a red circle. Municipalities with an absolute decrease in population between 1950 and 2000 are marked with purple hatching.

investigation started in 1950, resulting in a negligence of earlier developments. On the other hand the municipalities with an above-average increase in values within the last five decades were typically located in peripheral areas (for example the Calanca valley, see Figure 3). The explanation for this development lies in the tourism boom in the 1960s and 1970s, particularly the development of winter tourism, resulting in fundamental structural changes and a corresponding accumulation of tangible assets in certain regions.

\subsection{DEVELOPMENT OF LOSSES IN THE CANTON OF GRISONS}

Between 1950 and 2000, 573 avalanches in the canton of Grisons, which together caused 1,766 instances of damage to buildings, were documented in a database at the SLF (see Laternser et al., 1995). A detailed analysis of the damage pattern had shown that $50 \%$ of the events damaged only one building. In 111 events, five or more buildings were damaged, and in 42 events, 10 or more were damaged. The most extreme events were recorded in the "avalanche winter" of 1950/1951 (see Table I). The analysis of such events had shown that within the last 50 years, the most destructive avalanches of the canton occurred in the district of Davos.

Between 1950 and 2000, the total sum of avalanche losses due to direct building damage in Grisons amounted to $€ 63.3$ million. This is $40 \%$ of the sum paid by the building insurance company for all losses due to natural hazards in Grisons, but avalanches make up only $15 \%$ of the number of all incidents. This means an average of $€ 1.25$ million per year, compared with $€ 1.77$ million per year for losses due to other natural hazards, such as debris

Figure 3. Development of the average insurance value per building in the canton of Grisons for the period between 1950 and 2000. The figure illustrates the increase in the average insured values on a municipal level by standard deviations from the mean, which is 3.39 for the whole canton. The comparison with Figure 2 shows that large increases coincide with districts with below-average growth rates in residential population, like the Calanca valley (red circle). Below-average growth occurred in the regions of Lower Engadin, the Bernina pass and in the municipalities of the Rhine valley business area (green circles). 


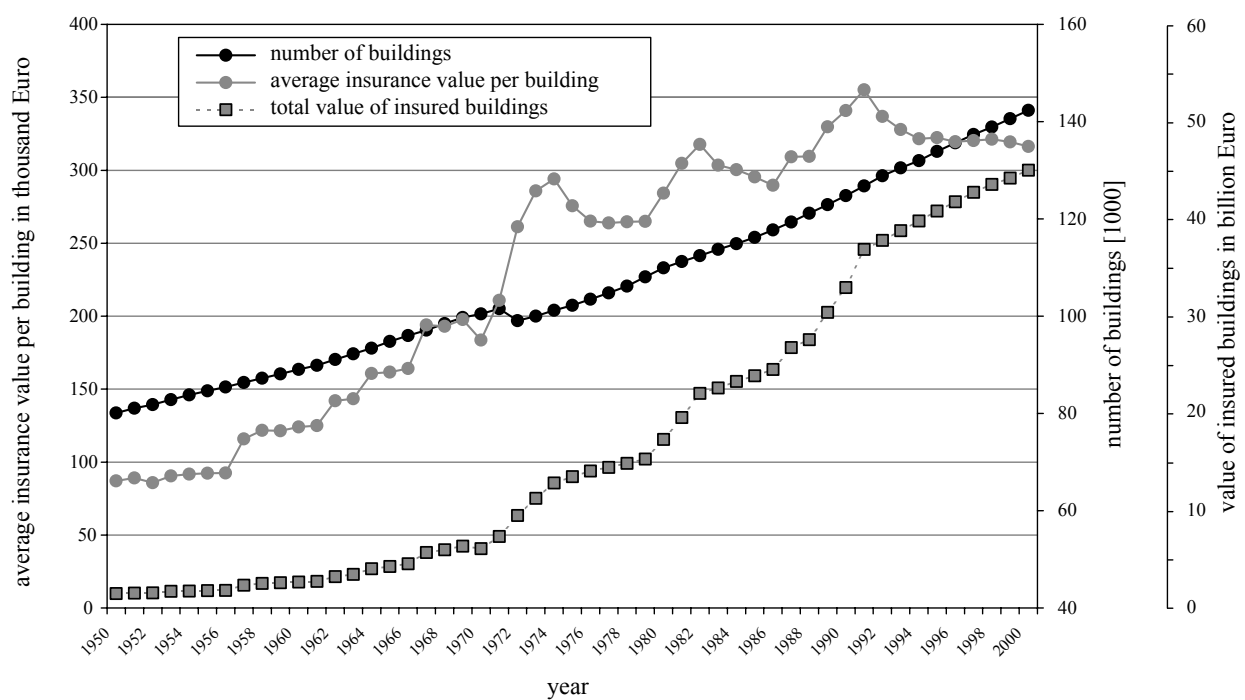

Figure 4. Development of values in the canton of Grisons. The number of insured buildings (mandatory insurance) has doubled. The total value of the insured buildings amounts to $€ 45$ billion, the average insured value per building having risen by a factor of 3.4 .

flows, rock fall events and floods. Damage resulting from avalanches amounted to $€ 17,500$ per event on average, while losses caused by other types of natural hazard processes cost $€ 6,000$ per event on average. For this reason, it can be postulated that avalanche damage is the most expensive elementary loss in the canton of Grisons.

Regarding the cost of the losses caused by avalanches, a tendency towards reduction in annual damage costs is detectable in extreme winters (see Figure 5), but with no statistical significance because of the independence of the extreme events. The same pattern can be recognised when calculating the damage ratio, which represents damage cost in Cents per 1,000 € insured sum. This tendency can be attributed to the realisation of mitigation measures, such as snow supporting structures in starting zones.

\subsection{DEVELOPMENT OF SETTLEMENTS IN DAVOS}

As shown in Figure 6, the density of buildings within the municipality of Davos has risen considerably during the last six decades. By the year 2000, almost the entire valley bottom was heavily built up. The avalanche-prone south-exposed slopes in particular showed a high density of development. The analysis of the number of buildings inside the zoning plan had shown that 1,024 buildings had been constructed between 1950 and 2000, with a total insured value of $€ 1.4$ billion. The average value of buildings amounted 
Table I. The highest losses resulting from catastrophic snow avalanches in Grisons, Switzerland, between 1950 and 2000

\begin{tabular}{|c|c|c|}
\hline Date & Municipality & Damage \\
\hline 20th January 1951 & Langwies & 33 buildings damaged \\
\hline 20th January 1951 & Zuoz & $\begin{array}{l}32 \text { buildings damaged, in- } \\
\text { cluding } 18 \text { residential build- } \\
\text { ings }\end{array}$ \\
\hline 20th January 1951 & St. Antönien & $\begin{array}{l}42 \text { buildings damaged, in- } \\
\text { cluding } 9 \text { residential buildings }\end{array}$ \\
\hline 20th January 1951 & St. Antönien-Ascherina & 25 buildings damaged \\
\hline 20th January 1951 & Vals & $\begin{array}{l}24 \text { buildings damaged, in- } \\
\text { cluding } 11 \text { residential build- } \\
\text { ings }\end{array}$ \\
\hline 26th January 1968 & Davos & $\begin{array}{l}33 \text { buildings damaged, in- } \\
\text { cluding } 29 \text { residential build- } \\
\text { ings }\end{array}$ \\
\hline 06th April 1975 & Vals & $\begin{array}{l}24 \text { buildings damaged, in- } \\
\text { cluding } 4 \text { residential buildings }\end{array}$ \\
\hline 06th April 1975 & Medel (Lucmagn) & $\begin{array}{l}23 \text { buildings damaged, in- } \\
\text { cluding } 3 \text { residential buildings }\end{array}$ \\
\hline 12th January 1977 & Braggio & $\begin{array}{l}27 \text { buildings damaged, in- } \\
\text { cluding } 16 \text { residential build- } \\
\text { ings }\end{array}$ \\
\hline
\end{tabular}

Most of the losses occurred in the avalanche winter of 1950/1951.

to $€ 1.4$ million. However, there were large differences depending on the type of construction, ranging from a barn valued at $€ 32,000$ to an apartment complex valued at €7.5 million. Even though Davos is not a peripheral area, $36 \%$ of the buildings were erected or re-built in the 1960 s, and $25 \%$ in the 1970s (see Figure 7). The fact that almost two thirds of the new buildings were constructed within 20 years demonstrates the economic prosperity of the region in this period. The cumulative graph of the insured values verifies this development, which can be explained by the high pressure in demand for building land during that time as well as by a gap in the "second building law" of 1961 (Günter, 1986). In this law, the construction of buildings in avalanche-endangered areas was forbidden; the appropriate hazard zones, however, were not necessarily specified. In the 1980s and 1990s, relatively few buildings were constructed (16 and $13 \%$ of the total number of buildings, respectively). The main reason for this was the decline in development sites. However, an increasing density in development is noticeable, which can be attributed to the building law of 1977, in which obligatory statements 


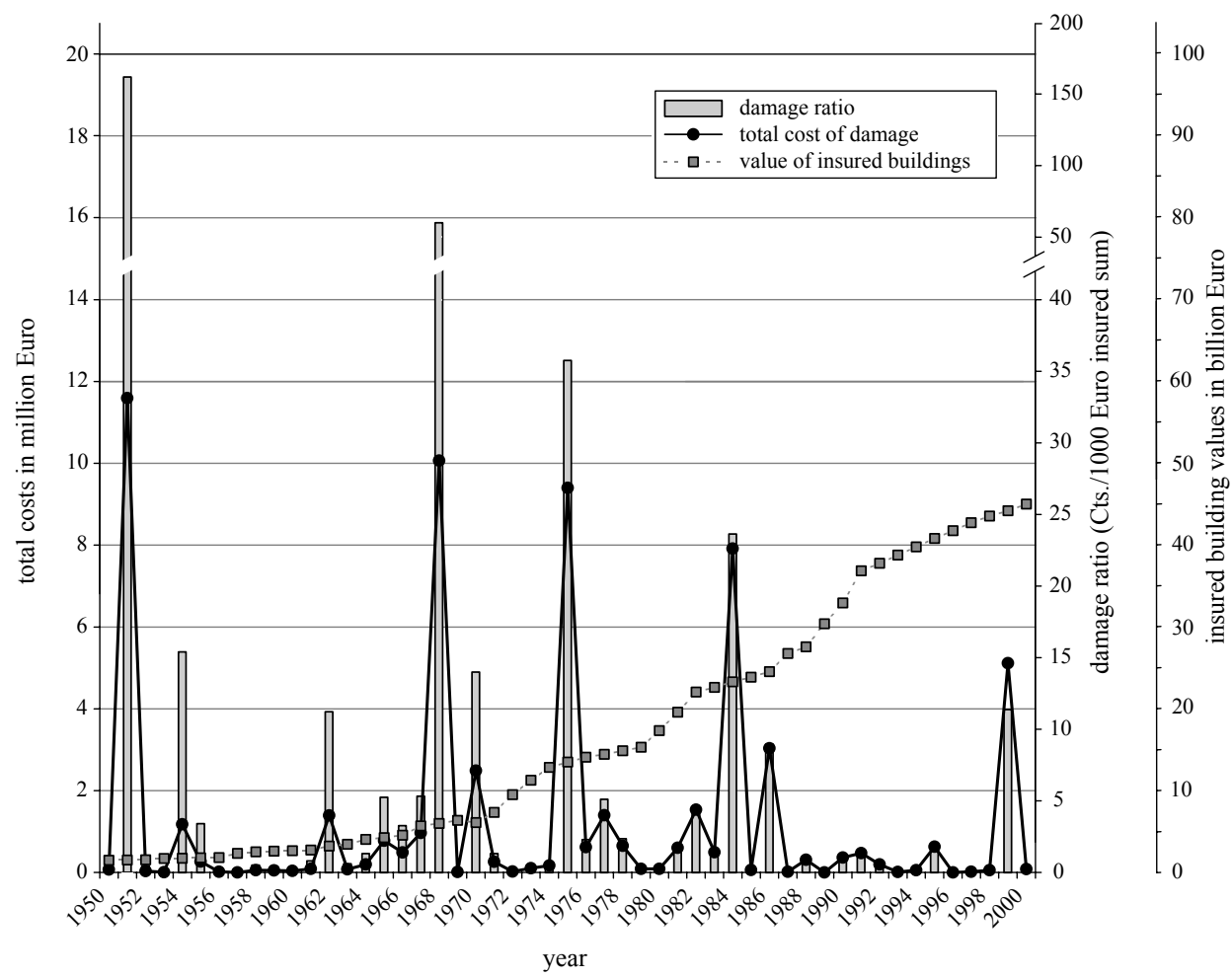

Figure 5. Costs resulting from avalanche damage in Grisons. Every extreme winter is a single event, which makes an exact comparison difficult, but the total costs and the damage ratios in extreme winters are declining. This can be carefully attributed to the realisation of mitigation measures. The insured building values increased steadily to arrive at $€ 45$ billion in the year 2000 .

concerning the maximum permissible floor space index (a parameter used in local planning, regulating the size of a building in relation to the size of the plot) were missing (Günter, 1986).

As described in Section 2, the study area was reduced to those lots that could be affected by avalanches. Within these defined investigation areas, 230 buildings were located, 174 of which were constructed between 1950 and 2000. Their insured values amounted to $€ 166$ million. Almost $60 \%$ of the buildings, with a total insured value of $€ 92.5$ million, were built in the 1960s; the graph of the insured values shows a strong increase during this period (see Figure 7). Only around 20 buildings were constructed during each of the subsequent decades, with an insured value of $€ 70$ million. The first hazard map and, as a consequence, the first land use regulations, were set up in the year 1977, when two thirds of the buildings with particularly high values had already been constructed. 

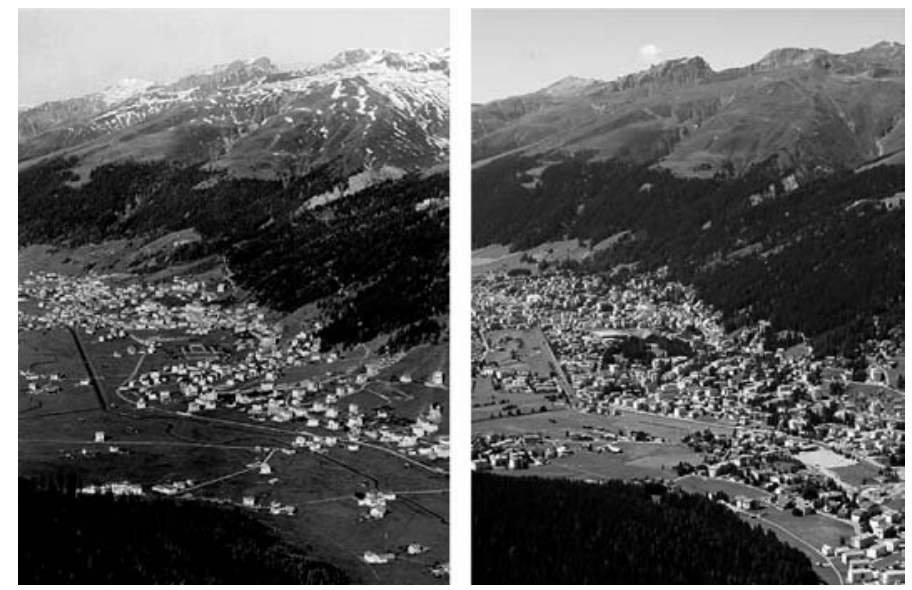

Figure 6. These photos show the increasing density of buildings in the municipality of Davos (Davos-Dorf and Davos-Platz). The photo on the left was taken around 1940. The valley bottom is sparsely built up, and the south-east-exposed hill slopes show a light forest which favoured destructive avalanches in the settlement. The photo on the right was taken in the year 2002 and illustrates the growth of the settlement. The buildings are located further up the slopes and reafforestation is apparent. Source: J. Trauffer, Davos (left); S. Fuchs, Davos (right).

The analysis of the number of buildings within the hazard zones (red, blue, yellow) and the buffer zone indicated that most development took place in the blue zone. Since 1950, 98 buildings, with a value of $€ 86.5$ million, were constructed there. Forty buildings ( $€ 60$ million) were constructed in contact with the directly affiliated buffer zone. Inside the red zone, 27 buildings were erected ( $€ 15$ million), while 9 buildings were erected within the yellow zone ( $€ 5$ million). At present, 26 residential buildings are located inside the red zone, where further development is forbidden by law. However, when they were built, these buildings were not located in the red zone. In 2000, 79 residents were registered as living inside red zones and 553 in blue zones.

The buffer zone is interpreted as an area of potential spatial error of the hazard zones. The damage potential would increase saliently when expanding the blue hazard zone by $10 \mathrm{~m}$. The proportional damage potential in the buffer zone amounts to $23 \%$ for the number and $36 \%$ for the value of all buildings inside areas affected by avalanches.

Towards the valley bottom, buildings were increasingly expensive: Inside the red zone, the insured mean value of buildings was $€ 0.5$ million, inside the blue zone it was €1.0 million, and inside the buffer zone it was $€ 1.5$ million. Buildings inside the area affected by avalanches had an average value of $€ 954,000$, compared to $€ 1.4$ million outside the process area. 


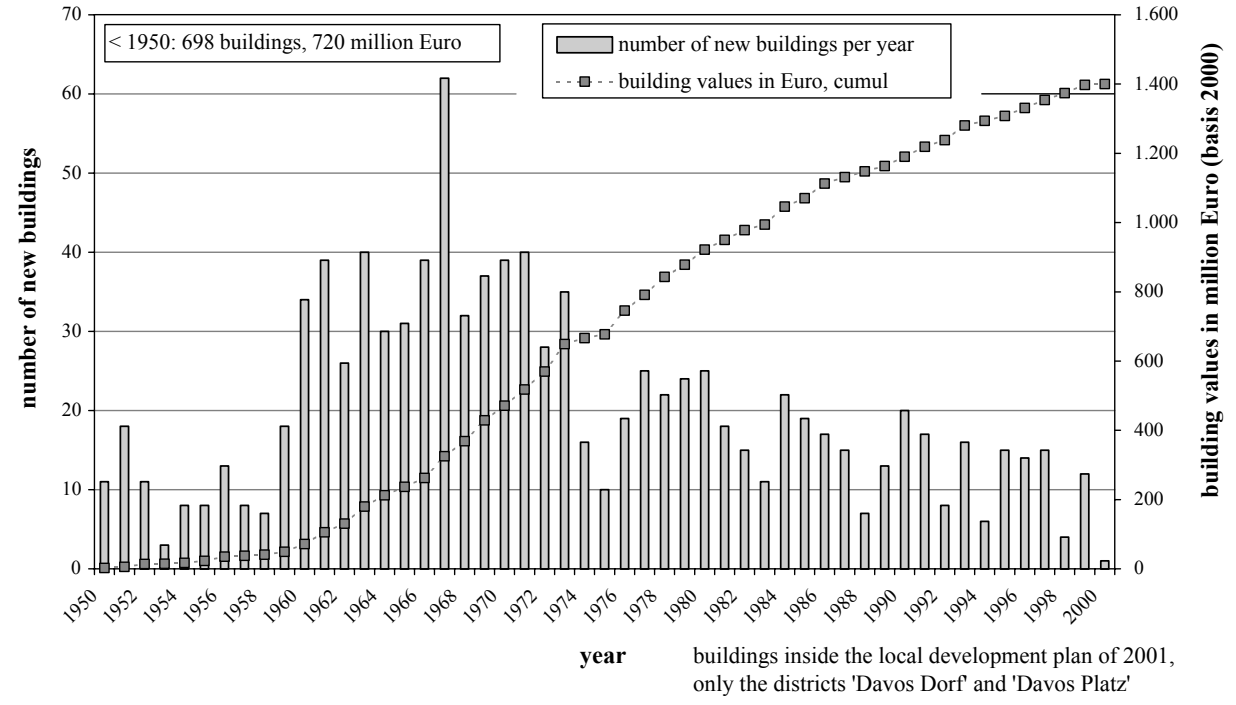

Figure 7. Development of buildings in Davos. The number of new buildings shows a clear peak between 1960 and 1975, a time of economic prosperity. In the subsequent decades, a gradual decrease in building activities occurred due to the decline in available development sites. The cumulated insurance values show a relatively high growth rate in the 1960s and a lower subsequent growth rate.

\subsection{CASE STUDY RUN-OUT ZONE "ALBERTITOBEL"}

Figure 8 shows the avalanche run-out zone 'Albertitobel' with the hazard map and the corresponding damage potential as a typical part of the study area. Six buildings were inside the red zone, 15 inside the blue zone and 11 in the buffer zone. The insured values of the buildings in all three zones amounted to $€ 52.6$ million. Twenty-six people lived inside the red zone, 128 inside the blue zone and 157 inside the buildings in the buffer zone (permanent residential population). It has to be emphasised that a slight extension of the blue hazard zone by $10 \mathrm{~m}$ would have a high influence on the affected damage potential, because $34 \%$ of the number of buildings are located inside the buffer zone, and approximately half of the people live there.

The problem of evaluating human life, which was mentioned in the introduction, is exemplified by an analysis of data relating to this area. Such an evaluation serves to indicate possible losses in the same arithmetic and logical units as for the buildings. Here we adopt the so-called human capital approach to evaluate these people's lives following the suggestions in Wilhelm (1997b). This approach is based on the assessment of the future income of a person that would be lost as a result of the premature death of that person. A variety of attempts and suggestions exist for the calculation of the 


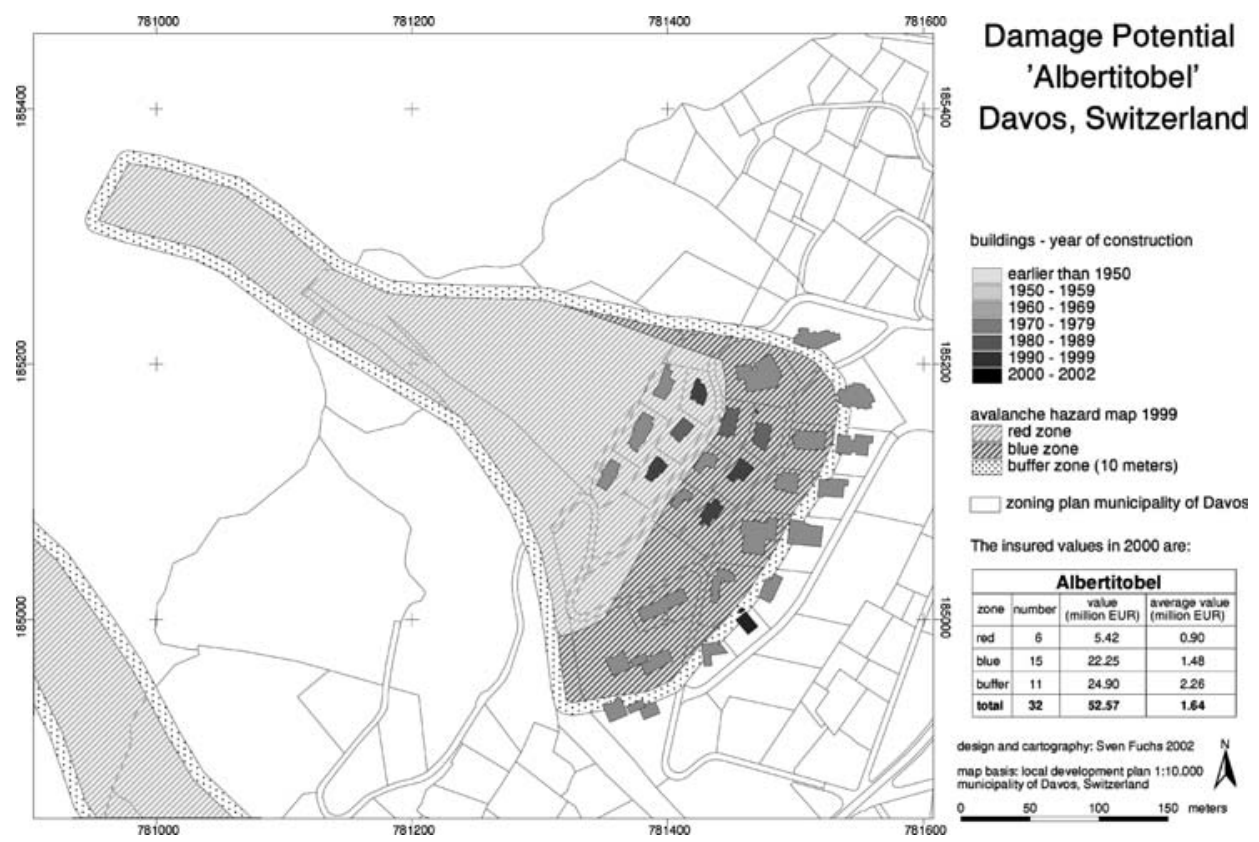

Figure 8. This figure of the test site "Albertitobel"/Davos demonstrates the method used. The number of endangered buildings and their insured value were calculated for every hazard zone and can also be retrieved by entering the year of construction.

human capital approach, but there is no generally accepted model (see Berg et al., 1994).

In the process area "Albertitobel", these future incomes were estimated to have an average value of $€ 1$ million per person, which amounts to $€ 311$ million for the whole permanent residential population in the area. Two main problems arose during this procedure, showing the sensitivity of the results to the economic assessment of the affected population.

Firstly, if the assessment of damage potential included human life measured in monetary terms, a bias appeared with regard to the material losses: the value of $€ 311$ million exceeded that of the insured buildings by a factor of 6 . This value is not in proportion to the existing non-material damage potential, and would consequently lead to a misinterpretation when mitigation measures were performed on the basis of cost-benefit-analyses: expensive investments in mitigation measures have to be carried out in regions with relatively high population but relatively low building structure.

The second problem arose during the evaluation of the residential population, when taking a closer look at the number of inhabitants. The average number of persons per building is 4.3 in the red zone and 8.5 in the blue zone. If the damage potential for the "Albertitobel" included human life measured 
in monetary terms, the values inside the blue zone would be overrated in comparison to the red zone due to an almost double weighting of the total value. This is an artefact of the method applied in our study. Therefore we used the clear number of affected persons and not an economic value when taking into account potential loss of life.

\subsection{INCREASE IN VALUES VERSUS INFLATION RATE}

The increase in values described above can result from two different factors: first, the increase in the number of buildings inside the process areas raises the insured values. The second factor is inflation: even if the number of buildings had remained constant, an increase in values could taken place. Between 1950 and 2000, approximately one fifth of the total increase in insured values can be ascribed to inflation, whereby the differences between several price indices can be ignored: The construction cost index differs from the national index of consumer prices for the year 1950 compared to the year 2000 by only 0.06 percentage points. The largest differences between these two indices can be found in the investigation period in the 1980s, when construction costs rose more than $10 \%$ points above the consumer price index. This is, in addition to a shortage of building land and the emerging legal restrictions, possibly a further reason for the decline in the construction volumes since the 1970s.

\section{Conclusions}

At present, in the field of natural hazards, risk analyses are increasingly used to evaluate negative effects of potentially dangerous natural processes. In accordance with the general risk Equation (1), risk depends on the probability of occurrence of a certain process and the related extent of the possible damage. Whereas data concerning the first are available in a relatively high quality, sufficient data to the latter is still missing so far. In order to close this gap, at least for parts of the Swiss Alps, we accomplished the investigation concerning the development of damage potential and losses from snow avalanches in settlements of the canton of Grisons.

The change of damage potential was quantified temporally and spatially. As pointed out in the previous sections, the damage potential has changed fundamentally during the last 50 years. The total number of mandatorily insured buildings increased in this period, whereby strong spatial mismatches arose between areas where the increase of insured buildings was above average (active areas) and areas where the increase was below average (passive areas). A parallel increase in the residential population can be registered, but with major differences between the different areas of the canton of Grisons. Thus, on the macroscale investigation level, the damage potential of tangible assets in Grisons must have increased by a factor of at least 3-4. 
On a microscale investigation level, individual process-relevant areas from the district of Davos were assessed. The number of buildings and the number of people living within endangered areas has increased remarkably. The damage potential rose substantially in the examined plots, particularly during the 1960s and 1970s. Thereby, the inflation-conditioned increase in the values is exceeded by a factor of 5 by an actual increase of buildings due to value concentration. Additionally, the investigation has shown how sensitive the determination of damage potential reacts on relatively small spatial enlargements of the blue hazard zones: the endangered values would increase by one third if the blue zones were extended by $10 \mathrm{~m}$.

In contrast to this, damage costs caused by avalanches have decreased in the canton of Grisons: the reduction of the insurance payments, in particular in the so-called "avalanche winters", leads to the conclusion that due to the implemented mitigation measures, further damage was averted or at least reduced. A gradual increase in risk takes place as a consequence of the gradual land development of endangered ranges. This means that high damage rates could arise locally in the case of extreme weather events like those of the winter of 1998/1999. For this reason, controlling settlement activities by means of effective development planning is indispensable.

Regional planning targets are to ensure sustainable and well-regulated land use, especially in regions such as mountain areas, where land is scarce. Urban land use planning, including local development plans and hazard maps, are suitable controlling mechanisms. However, the question of the effectiveness of these regulations arises due to the fact that in Switzerland, approximately 25\% of all buildings are located outside areas that have controlled land use (Wüest and Rey, 1994). In Davos, $23 \%$ of all buildings inside the avalanche process zones are located in areas without a valid development plan. In those areas, special conditions or building restrictions cannot be enforced.

\section{Appendix}

It is the responsibility of the Swiss cantons to protect people's life and property from natural hazards such as avalanches, landslides, erosion and rockfalls in accordance with the Federal Law of 22nd June 1979 relating to land-use planning. Further implementation instructions result from the appropriate articles in the Federal Law of 4th October 1991 relating to forests and the Federal Law of 21st June 1991 relating to hydraulic engineering. According to these laws and associated decrees, the appropriate specialised offices of the federal authorities have to compile guidelines to encourage the consideration of natural hazards in land-use planning. The principles for general planning issues are published in Heinimann et al. (1998), whereas the "guidelines for the consideration of the avalanche danger 
in land-use planning activities" have been approved in 1984 (BFF and SLF, 1984). These guidelines describe the two main instruments for the inclusion of avalanche danger in land-use planning, namely avalanche incident documentation and the avalanche hazard map. This hazard map divides an examined area into different subsections with different danger stages due to severity and likelihood of potential avalanche hazards (BFF and SLF, 1984).

Red indicates areas where avalanches with a pressure of up to $30 \mathrm{kN} / \mathrm{m}^{2}$ or more and a reoccurrence interval of up to 300 years take place or, alternatively, where avalanches with less pressure than $30 \mathrm{kN} / \mathrm{m}^{2}$ but a reoccurrence interval up to 30 years occur.

Blue shows areas with a snow avalanche pressure of less than $30 \mathrm{kN} / \mathrm{m}^{2}$ and a reoccurrence interval of between 30 and 300 years. Regions with powder avalanches with less than $3 \mathrm{kN} / \mathrm{m}^{2}$ and lower reoccurrence intervals than 30 years are also marked in blue.

The run-out areas of powder avalanches with a pressure lower than $3 \mathrm{kN} /$ $\mathrm{m}^{2}$ and reoccurrence intervals higher than 30 years are marked in yellow, as well as theoretically not excludable but extremely rare avalanches with a reoccurrence interval higher than 300 years.

\section{Acknowledgements}

The authors want to thank M. Fischer of the GVA building insurance company of Grisons, for providing the necessary database; M. Keiler, J. Stötter, H. Weck-Hannemann of the University of Innsbruck, Austria and C. Wilhelm of the forestry office, Grisons, for discussion and valuable comments; and two anonymous reviewers for their suggestions improving the paper. The research for this paper was carried out with the support of a grant from MunichRe reinsurance company, Germany.

\section{References}

Bätzing, W.: 1993, Der sozio-ökonomische Strukturwandel des Alpenraumes im 20. Jahrhundert, Geogr. Bernens. P26, 1-156.

Berg, M., Erdmann, G., Jaggy, M., Scheringer, M., and Seiler, H.: 1994, Was ist ein Schaden? vdf-Hochschulverlag, Zürich, $251 \mathrm{pp}$.

Berz, G.: 2000, Naturkatastrophen an der Wende zum 21. Jahrhundert: Weltweite Trends und Schadenpotentiale, In: V. Linneweber (ed.), Zukünftige Bedrohungen durch (anthropogene) Naturkatastrophen, Schriftenreihe des DKKV 22, Bonn, pp. 4-15.

BFF and SLF (eds): 1984, Richtlinien zur Berücksichtigung der Lawinengefahr bei raumwirksamen Tätigkeiten, Davos und Bern, 35 pp.

Borter, P.: 1999, Risikoanalyse bei gravitativen Naturgefahren, Bern, In: BUWAL (ed.), Umwelt-Materialien, Vols. 107/I, II, 115 and 129 pp. (two volumes). 
Fuchs, S., Keiler, M., and Zischg, A.: 2002, An information system on natural hazards, based on risk analysis, In: R. Bottarin and U. Tappeiner (eds), Interdisciplinary Mountain Research, Blackwell Science, Berlin, pp. 82-90.

Günter, T.: 1986, Nutzungsgeschichte, In: O. Wildi and K. Ewald (eds), Der Naturraum und dessen Nutzung im alpinen Tourismusgebiet von Davos. Ergebnisse des MAB-Projektes Davos, Berichte der Eidgenössischen Anstalt für das forstliche Versuchswesen, Vol. 289, Birmensdorf, pp. 215-238.

Heinimann, H., Hollenstein, K., Kienholz, H., Krummenacher, B., and Mani, P.: 1998, Methoden zur Analyse und Bewertung von Naturgefahren, Bern, In: BUWAL (ed.), UmweltMaterialien, Vol. 85, 248 pp.

Jakobi, W., Kron, W., and Berz, G.: 2001, Versicherung, In: J. Plate and B. Merz (eds), Naturkatastrophen. Ursachen, Auswirkungen, Vorsorge, Schweizerbart, Stuttgart, pp. 408421.

Jamieson, B. and Stethem, C.: 2002, Snow avalanche hazards and management in Canada: Challenges and Progress, Natural Hazards 26, 35-53.

Jóhannesson, T. and Arnalds, p.: 2001, Accidents and economic damage due to snow avalanches and landslides in Iceland, Jökull 50, 81-94.

Laternser, M.: 2002, Snow and Avalanche Climatology of Switzerland, Dissertation 14493, Swiss Federal Institute of Technology, Zürich, 137 pp.

Laternser, M., Lentner, S., Meier, R., Schneebeli, M., and Utelli, H.-H.: 1995, Dokumentation zur Schadenlawinen-Datenbank (SLDB), Vol. 690, Swiss Federal Institute for Snow and Avalanche Research SLF, Davos, Interner Bericht, 62 pp.

Munich Re (ed.): 2003, Topics - Annual Review: Natural Catastrophes 2002, Munich Re, Munich, $48 \mathrm{pp}$.

Nöthiger, C., Elsasser, H., Bründl, W., and Ammann, W.: 2002, Indirekte Auswirkungen von Naturgefahren auf den Tourismus - Das Beispiel des Lawinenwinters 1999 in der Schweiz, Geogr. Helvet. 2, 91-108.

Renn, O.: 1992, Concepts of risk: A classification. In: S. Krimsky and D. Golding (eds), Social Theories of Risk, Praeger, London, pp. 53-79.

Schneebeli, M., Laternser, M., Föhn, P., and Ammann, W.: 1998, Wechselwirkungen zwischen Klima, Lawinen und technischen Massnahmen. Schlußbericht NFP31, vdf-Hochschulverlag, Zürich, $132 \mathrm{pp}$.

SLF (ed.): 2000, Der Lawinenwinter 1999. Swiss Federal Institute for Snow and Avalanche Research, Davos, 588 pp.

Varnes, D.: 1984, Landslide Hazard Zonation: A Review of Principles and Practice, Unesco, Paris, $63 \mathrm{pp}$.

Viscusi, W.: 1993, The value of risks to life and health, J. Econ. Lit. 31, 1912-1946.

Wanner, H., Gyalistras, D., Luterbacher, J., Rickli, R., Salvisberg, E., and Schmutz, C.: 2000, Klimawandel im Schweizer Alpenraum, vdf-Hochschulverlag, Zürich, 285 pp.

Watson, R. and the Core Writing Team (eds): 2001, Climate Change 2001, Synthesis Report, Cambridge University Press, Cambridge, 397 pp.

Wilhelm, C.: 1997a, Zur Entwicklung des Lawinenrisikos in der Schweiz, In: Proc. Risikobewertung und Naturraumprävention von Wildbächen und Lawineneinzugsgebieten, University of Agricultural Science Vienna, 24.-25.09.1997, pp. 112-127.

Wilhelm, C.: 1997b, Wirtschaftlichkeit im Lawinenschutz. Mitteilungen des Eidgenössischen Instituts für Schnee- und Lawinenforschung, Vol. 54, Davos, pp. 1-309.

Wüest, H. and Rey, U.: 1994, Bauten ausserhalb der Bauzonen. Eine Bestandsaufnahme, Bundesamt für Raumplanung, Bern, 53 pp. 